\title{
UJI EFEK ANALGESIK INFUSA DAUN KAYU PUTIH (Melaleuca trichostachya Lindl.) PADA MENCIT JANTAN (Mus musculus L.)
}

\section{(EFFECTS TEST ANALGESICS INFUSE WHITE WOODEN LEAF (Melaleuca trichostachya Lindl.) IN MALE MICE (Mus musculus L.))}

\author{
ERNA CAHYANINGSIH ${ }^{\bullet}$, ELIS SUWARNI $^{1}$ \\ ${ }^{1}$ Akademi Farmasi Saraswati Denpasar, Jalan Kamboja No. 11A, Denpasar, Bali
}

\begin{abstract}
Abstrak: Tanaman kayu putih (Melaleuca trichostachya Lindl.) dari familia Myrtaceae termasuk dalam tumbuhan obat yang sudah dimanfaatkan untuk pengobatan tradisional di Indonesia salah satunya sebagai analgesik. Beberapa senyawa yang terkandung dalam kayu putih yang diduga bersifat analgesik antara lain terpineol. Tujuan dari penelitian ini untuk mengetahui adanya efek analgesik dari infusa daun kayu putih (Melaleuca trichostachya Lindl.) pada mencit jantan (Mus musculus L.). Penelitian ini ialah penelitian eksperimental dengan menggunakan metode rangsang panas pada suhu $55^{\circ} \mathrm{C}$. Pada penelitian ini digunakan hewan uji berupa mencit jantan yang dibagi dalam lima kelompok masing-masing terdiri dari 5 ekor mencit. Kelompok kontrol positif diberi asetosal $1,3 \mathrm{mg} / 20 \mathrm{~g} \mathrm{BB}$, kelompok kontrol negatif diberi aquadest $2,5 \mathrm{ml} / 100 \mathrm{~g}$ BB, kelompok uji diberi infusa daun kayu putih konsentrasi 5\%, 10\% dan 20\% masing-masing 2,5ml/100g BB. Pengamatan dilakukan setelah 15 menit pemberian sampel ketika mencit diletakkan di atas hot plate. Data yang diperoleh selanjutnya dianalisis dengan metode statistik (ANOVA). Hasil penelitian menunjukkan bahwa terjadi peningkatan waktu munculnya respon mencit (pertama kali menjilat kakinya), pada kelompok yang diberi infusa daun kayu putih. Berdasarkan hasil dapat disimpulkan bahwa infusa daun kayu putih memiliki efek analgesik pada mencit jantan.
\end{abstract}

Kata kunci: Analgesik, infusa daun kayu putih, rangsang panas.

\begin{abstract}
Eucalyptus plants (Melaleuca trichostachya Lindl.) of familia Myrtaceae included in a medicinal plant that has been used for traditional medicine in Indonesia one of them as an analgesic. Some of the compounds contained in eucalyptus putatively analgesics include terpineol. The purpose of this study to investigate the analgesic effect of infusion of eucalyptus leaves (Melaleuca trichostachya Lindl.) in male mice (Mus musculus L.). This study is an experimental study using thermal stimulation at $55^{\circ} \mathrm{C}$. In this experiment, the test animals in the form of male mice were divided into five groups each consisting of 5 mice. The positive control group was given aspirin $1.3 \mathrm{mg} / 20 \mathrm{~g} \mathrm{BB}$, negative control group were given distilled water $2.5 \mathrm{ml} / 100$ $\mathrm{g} \mathrm{BB}$, the test group was given eucalyptus leaves infuse concentration of 5\%,10\% and $20 \%$ each $2.5 \mathrm{ml} / 100$ g BB. Observations were made after 15 minutes of administration of the sample when the mice were placed on a hot plate. The data were then analyzed with statistical methods (ANOVA). The results showed that an increase in the response time of the emergence of mice (first lick feet), the group given infusion of eucalyptus leaves. Based on the results it can be concluded that infuse the leaves of eucalyptus have analgesic effect in male mice.
\end{abstract}

Keywords: Analgesics, infuse eucalyptus leaves, heat stimuli.

\section{PENDAHULUAN}

Indonesia merupakan salah satu negara dengan kekayaan hayati terbesar di dunia yang memiliki lebih dari 30.000 spesies tanaman tingkat tinggi. Hingga saat ini, tercatat 7000 spesies tanaman telah diketahui khasiatnya namun kurang dari 300 tanaman yang digunakan sebagai bahan baku industri farmasi secara regular (Saifudin, dkk., 2011).
Sejak ribuan tahun yang lalu pengobatan tradisional juga sudah ada di Indonesia jauh sebelum pelayanan kesehatan formal dengan obatobatan modern dikenal masyarakat. Obat-obat tradisional cenderung sesuai dengan kultur masyarakat Indonesia, mudah di dapat, murah, dan aman dengan efek sampingnya yang relatif kecil. Kekayaan tumbuhan obat ini juga mendukung kecenderungan masyarakat saat ini untuk kembali ke alam (back to nature) dalam upaya mencapai kesehatan yang optimal (Atikaningrum, 2011).

\footnotetext{
- email korespondensi: ernafar08@gmail.com
} 
Salah satu tumbuhan yang berkhasiat adalah daun kayu putih (Melaleuca trichostachya Lindl.) dari familia Myrtaceae. Hampir semua bagian tanaman ini (kulit batang, daun, ranting, dan buah kayu putih) dapat dimanfaatkan sebagai obat. Kandungan daun kayu putih sineol, melaleucin, minyak atsiri yang terdiri dari terpineol, cineol dan lignin (Thomas, 1992 dalam Tuhu, 2008). Kandungan daun kayu putih yang mempunyai efek analgetik adalah terpineol (Tuhu, 2007). Secara empirik, daun kayu putih berkhasiat untuk menghilangkan bengkak dan nyeri (analgetika). Khasiat lain dari daun kayu putih antara lain untuk sakit radang usus, diare, reumatik, asma, radang kulit ekzema, insomnia dan sakit kepala. Pengobatan dapat dilakukan dengan meremas daun kayu putih lalu diletakkan pada bagian tubuh yang sakit atau dapat juga dilakukan dengan meminum rebusan daun kayu putih ini (Tuhu, 2008).

Analgesik adalah bahan atau obat yang digunakan untuk menekan atau mengurangi rasa sakit atau nyeri tanpa menyebabkan hilangnya kesadaran. Analgetik terbagi menjadi dua kelompok utama yaitu analgetik opioid dan analgetik nonopioid. Analgetik opioid merupakan kelompok obat yang selain memiliki efek analgetik, juga memiliki efek seperti opium (Gunawan, 2008 dalam Pandey, dkk., 2013).

Penelitian dilakukan oleh Tuhu, dkk., 2007, menunjukkan bahwa ekstrak etanol daun kayu putih (Melaleuca leucadendron L.) memiliki efek analgesik pada mencit jantan (Mus musculus). Pembuatan infusa merupakan cara paling sederhana untuk membuat sediaan herbal dari bahan lunak seperti daun dan bunga yang dapat diminum panas atau dingin (Direktorat Obat Asli Indonesia, 2010 dalam Seran, 2015). Mengingat belum adanya penelitian dalam bentuk infusa daun kayu putih, maka peneliti akan melakukan uji efek analgesik dari infusa daun kayu putih (Melaleuca trichostachya Lindl.) pada mencit jantan (Mus musculus L.).

\section{BAHAN DAN METODE}

Bahan. Bahan tanaman yang digunakan untuk penelitian ini adalah daun kayu putih (Melaleuca trichostachya Lindl.) yang tumbuh di Desa Tibubeneng, Badung, Bali, dan telah di identifikasi oleh suatu Lembaga Ilmu Pengetahuan Indonesia UPT Balai Konservasi Tumbuhan Kebun Raya "EKA KARYA" Bali.
Bahan lain yang digunakan sebagai penunjang penelitian ini adalah asetosal sebagai kontrol positif dan aquadest sebagai kontrol negatif.

Alat. Alat-alat yang digunakan dalam penelitian ini meliputi: alat-alat gelas umum yang terdapat di laboratorium kimia, kanul tumpul, stopwatch, timbangan, hot plate, panci infusa, dan kertas saring.

Hewan Percobaan. Pada pengujian ini digunakan hewan percobaan mencit jantan (Mus musculus L.) sehat berumur 2-3 bulan pada saat perlakuan uji dengan bobot mencit 20-28 g yang memiliki kondisi fisik sehat dan aktif.

Pembuatan Infusa Daun Kayu Putih. Untuk membuat $50 \mathrm{ml}$ infusa daun kayu putih 5\%, 10\% dan 20\%, masing-masing ditimbang serbuk simplisia daun kayu putih sebanyak: 2,5 g, $5 \mathrm{~g}$ dan 10g. Kemudian masing-masing simplisia dimasukkan ke dalam panci infusa, dan ditambahkan air sebanyak $50 \mathrm{ml}(2 \mathrm{x}$ bobot simplisia $+50 \mathrm{ml}$ ). Masing-masing panci infusa dipanaskan di atas pengangas air selama 15 menit terhitung dari suhu pelarut mencapai $90^{\circ} \mathrm{C}$, kemudian diserkai dan tambahkan aquadest ad 50 $\mathrm{ml}$.

Metode. Pada penelitian ini, dua puluh lima mencit jantan dikelompokkan menjadi 5 kelompok, masing-masing kelompok terdiri dari 5 ekor mencit jantan. Sebelum dilakukan pengujian, mencit terlebih dahulu diadaptasi selama 10 hari dan dipuasakan selama 6 jam. Kelompok A sebagai kontrol negatif diberi 2,5 ml/100 g BB aquadest, kelompok B sebagai kontrol positif diberi asetosal dengan dosis $1,3 \mathrm{mg} / 20 \mathrm{~g} \mathrm{BB}$, kelompok $\mathrm{C}, \mathrm{D}$ dan E sebagai kelompok uji diberi $2,5 \mathrm{ml} / 100 \mathrm{~g}$ BB infusa daun kayu putih dengan konsentrasi masingmasing 5\%, 10\%, dan 20\%. Masing-masing sampel diberikan secara oral. Hewan didiamkan selama 15 menit untuk memberikan kesempatan distribusi obat ke dalam tubuh. Selanjutnya dilakukan pengujian dengan menggunakan metode rangsang panas menggunakan alat hot plate dengan suhu konstan $55^{\circ} \mathrm{C}$. Tiap mencit ditaruh di atas hot plate, kemudian dicatat waktu reaksi yang diperlukan.

\section{HASIL DAN PEMBAHASAN}

Pada penelitian ini, telah dilakukan uji efek analgesik infusa daun kayu putih (Melaleuca trichostachya Lindl.) terhadap mencit jantan (Mus 
musculus L.). Daun kayu putih (Melaleuca trichostachya Lindl.) dari familia Myrtaceae yang digunakan diperoleh dari Desa Tibubeneng, Badung, Bali, sudah di determinasi oleh suatu Lembaga Ilmu Pengetahuan Indonesia UPT Balai Konservasi Tumbuhan Kebun Raya "EKA KARYA" Bali. Penelitian ini telah mendapatkan ijin kelaikan etis penelitian (ethical clearance) dari komisi etik penggunaan hewan dalam penelitian dan pendidikan. Secara empirik, daun kayu putih berkhasiat untuk menghilangkan bengkak dan nyeri (analgetika) (Tuhu, 2008). Adanya metabolit sekunder terpineol yang menyebabkan efek farmakologi sebagai analgesik. Berdasarkan penelitian dilakukan oleh Tuhu, dkk., 2007, daun kayu putih memiliki efek analgesik.

Analgesik adalah bahan atau obat yang digunakan untuk menekan atau mengurangi rasa sakit atau nyeri tanpa menyebabkan hilangnya kesadaran (Gunawan, 2008 dalam Pandey, dkk., 2013). Nyeri adalah perasaan sensoris dan emosional yang tidak nyaman, berkaitan dengan (ancaman) kerusakan jaringan (Tjay dan Rahardja, 2007).

Sampel uji diberikan dalam bentuk sediaan infusa yang dibuat dengan mengekstraksi simplisia nabati dengan air pada suhu $90^{\circ} \mathrm{C}$ selama 15 menit (Anonim, 1995). Efek analgesik infusa daun kayu putih (Melaleuca trichostachya Lindl.) dengan berbagai konsentrasi $(5 \%, 10 \%$ dan 20\%) menggunakan kontrol positif asetosal dengan dosis 1,3/20 g BB, kontrol positif berfungsi untuk membandingkan daya analgetika dengan sampel yang diteliti, juga dapat digunakan untuk membuktikan kevalidan dari metode yang digunakan (Tuhu, 2008). Asetosal digunakan sebagai pembanding karena asetosal sebagai analgesik antipiretik dan anti-inflamasi yang sangat luas digunakan dan digolongkan dalam obat bebas. Selain sebagai prototip, obat ini merupakan standar dalam menilai efek obat sejenis (Sardjono dkk., 1995). Sebagai kontrol negatif yaitu aquadest, volume pemberian $2,5 \mathrm{ml} / 100 \mathrm{~g}$ BB menggunakan metode induksi panas (hot plate method). Metode ini cukup peka untuk pengujian analgetika, obat yang mempunyai efek analgetika lemah pun dapat memberikan hasil positif (Tuhu, 2008).

Pada penelitian ini, digunakan daun kayu putih yang dipetik pada pagi hari, karena pada waktu pagi hari daun mampu menghasilkan rendeman minyak atsiri lebih tinggi dengan kualitas baik (Lutony, 1994). Daun kayu putih yang telah dikeringkan dengan cara diangin-anginkan dan tidak dipanaskan di bawah sinar matahari langsung. Pengeringan bertujuan untuk mendapatkan simplisia yang tidak mudah rusak oleh adanya pertumbuhan jamur sehingga dapat disimpan lebih lama. Daun kayu putih tersebut selanjutnya diblender untuk mendapatkan hasil yang halus. Tujuan pembuatan serbuk daun kayu putih agar diperoleh ukuran sampel yang lebih kecil sehingga lebih memperluas kontak antara penyari dengan permukaan serbuk dan mempermudah proses penyarian senyawa aktif (Seran, 2015).

Hewan percobaan yang digunakan pada penelitian ini adalah mencit jantan $\mathrm{Balb} / \mathrm{C}$ sebanyak 25 ekor mencit, yang berumur 2-3 bulan dengan berat badan 20-28 g dalam kondisi fisik yang sehat dan aktif. Mencit putih jantan digunakan dengan alasan kondisi biologisnya stabil bila dibandingkan mencit betina yang kondisi biologisnya dipengaruhi masa siklus estrus. Hal ini bertujuan untuk memperkecil variabilitas biologis antar hewan uji yang digunakan, sehingga dapat memberikan respon yang relatif lebih seragam terhadap rangsang kimia yang digunakan dalam penelitian ini (Tuhu, 2008). Mencit diadaptasikan selama 10 hari dan dipuasakan selama 6 jam sebelum diberikan perlakuan yang bertujuan agar mencit tidak merasakan lingkungan yang asing dan tidak mengalami stres atau depresi yang dapat mempengaruhi hasil pengujian.

Mencit dibagi secara acak menjadi 5 kelompok, masing-masing kelompok terdiri dari 5 ekor mencit. Mencit diberikan perlakuan sesuai dengan kelompoknya masing-masing. Kelompok kontrol negatif diberikan aquadest, kelompok kontrol positif diberikan asetosal, kemudian tiga kelompok uji diberikan infusa daun kayu putih (Melaleuca trichostachya Lindl.) dengan konsentrasi yang berbeda yaitu 5\%, 10\% dan 20\%. Semua pelakuan diberikan per oral sebanyak 2,5 $\mathrm{ml} / 100 \mathrm{~g}$ BB dengan cara di sonde ke dalam mulut mencit, rute pemberian oral adalah paling umum dilakukan karena mudah, aman dan murah (Syamsudin \& Darmono, 2011), mencit didiamkan selama 15 menit untuk memberikan kesempatan distribusi obat ke dalam tubuh.

Selanjutnya dilakukan pengujian dengan menggunakan metode cara panas menggunakan alat hot plate dengan suhu $55^{\circ} \mathrm{C}$. Induksi nyeri secara termik dalam penelitian ini menggunakan suhu konstan yaitu $55^{\circ} \mathrm{C}$, karena suhu kritis rata-rata sebesar $45^{\circ} \mathrm{C}$ saat seseorang mulai merasakan sakit dan reseptor panas mempunyai respon terhadap suhu $30-45^{\circ} \mathrm{C}$, suhu di atas $45^{\circ} \mathrm{C}$ mulai terjadi kerusakan jaringan akibat panas dan sensasinya berubah menjadi nyeri. Jadi, rasa nyeri yang disebabkan oleh panas sangat erat hubungannya dengan kemampuan panas untuk merusak jaringan 
(Turner,1965; Guyton, 1994; Ganong, 1999 dalam Puspitasari dkk., 2003). Setelah mencit diletakkan di atas hot plate, kemudian stopwatch dihidupkan sampai mencit merasakan nyeri yang ditandai dengan gerakan mencit menjilat kakinya. Dilakukan pencatatan waktu pertama kali menjilat kakinya.
Pada penelitian ini, pengamatan dilakukan terhadap waktu reaksi yang diperlukan. Waktu reaksi adalah selang waktu antara penempatan mencit di atas hot plate dan munculnya respon pertama pada mencit yaitu menjilat kakinya sebagai reaksi untuk mengurangi nyeri. Data hasil pengujian dapat dilihat pada tabel 1 .

Tabel 1. Waktu Munculnya Respon Nyeri Pada Mencit Jantan Balb/C

\begin{tabular}{|c|c|c|c|c|c|}
\hline \multirow[b]{3}{*}{ Mencit } & \multicolumn{5}{|c|}{ Waktu (Detik) Munculnya Respon Nyeri } \\
\hline & \multirow{2}{*}{$\begin{array}{c}\text { Kelompok } \\
\text { Kontrol } \\
\text { Negatif } \\
\text { (Aquadest) }\end{array}$} & \multirow{2}{*}{$\begin{array}{l}\text { Kelompok } \\
\text { Kontrol } \\
\text { Positif } \\
\text { (Asetosal) }\end{array}$} & \multicolumn{3}{|c|}{ Kelompok Uji } \\
\hline & & & $\begin{array}{c}\text { Infusa Daun } \\
\text { Kayu Putih } \\
\text { Konsentrasi } \\
5 \%\end{array}$ & $\begin{array}{c}\text { Infusa Daun } \\
\text { Kayu Putih } \\
\text { Konsentrasi } \\
10 \%\end{array}$ & $\begin{array}{c}\text { Infusa Daun } \\
\text { Kayu Putih } \\
\text { Konsentrasi } \\
20 \%\end{array}$ \\
\hline 1 & 6 & 14 & 7 & 14 & 15 \\
\hline 2 & 7 & 15 & 9 & 13 & 17 \\
\hline 3 & 8 & 16 & 9 & 15 & 18 \\
\hline 4 & 11 & 22 & 12 & 17 & 19 \\
\hline 5 & 12 & 26 & 12 & 17 & 25 \\
\hline Rata-rata & 8,8 detik & 18,6 detik & 9,8 detik & 15,2 detik & 18,8 detik \\
\hline
\end{tabular}

Dari tabel 1. dapat diketahui bahwa kelompok kontrol negatif yang diberi aquadest memiliki waktu reaksi rata-rata yaitu 8,8 detik. Kelompok kontrol positif yang diberi asetosal menunjukkan waktu reaksi rata-rata yaitu 18,6 detik. Kelompok uji yang diberi infusa daun kayu putih dengan kosentrasi 5\%, 10\%, dan 20\% menunjukkan peningkatan waktu reaksi rata-rata yaitu 9,$8 ; 15,2$ dan 18,8 detik. Hal ini menunjukkan bahwa baik asetosal maupun infus daun kayu putih dapat meningkatkan daya tahan mencit terhadap rasa nyeri yang ditimbulkan oleh rangsang panas dari hot plate.

Data yang diperoleh pada masing-masing kelompok perlakuan menghasilkan rata-rata durasi aktivitas motorik mencit yang berbeda-beda dan untuk mengetahui data itu berbeda signifikan atau tidak, maka dilakukan analisis dengan menggunakan metode Analisa Varian (ANOVA) menggunakan SPSS version 16 for windows. Dari uji ANOVA dapat diketahui bahwa hasil perbandingan antara kelompok kontrol positif (asetosal) dengan kelompok uji (infusa daun kayu putih pada konsentrasi 5\%, $10 \%$ dan 20\%) diperoleh sig $=0,004$ pada konsentrasi $5 \%$ berarti bahwa ada perbedaan bermakna, pada konsentrasi $10 \%$ dan konsentrasi $20 \%$ masing-masing sig = 0,507 dan sig $=1,000$, yang berarti bahwa tidak ada perbedaan bermakna antara kelompok kontrol positif dengan kelompok uji pada konsentrasi $10 \%$ dan $20 \%$.
Hasil kelompok kontrol negatif (aquadest) dengan kelompok uji (infusa daun kayu putih pada konsentrasi $5 \%$ ) diperoleh nilai sig $=0,989$ yang berarti bahwa tidak ada perbedaan bermakna antara kelompok kontrol negatif (aquadest) dengan kelompok uji (infusa daun kayu putih pada konsentrasi 5\%) sedangkan dengan kelompok uji (infusa daun kayu putih pada konsentrasi $10 \%$ dan $20 \%$ ) diperoleh nilai sig masing-masing yaitu pada konsentrasi $10 \%=0,046$ dan pada konsentrasi $20 \%$ $=0,001$ yang berarti bahwa ada perbedaan bermakna antara kelompok kontrol negatif (aquadest) dengan kelompok uji (infusa daun kayu putih pada konsentrasi $10 \%$ dan $20 \%$ ).

Dari hasil penelitian ini dapat diketahui bahwa seluruh kelompok uji yaitu kelompok mencit yang diberikan infusa daun kayu putih (Melaleuca trichostachya Lindl.) 10\% dan 20\% memiliki aktivitas sebagai analgesik.

\section{SIMPULAN}

Berdasarkan hasil penelitian dapat disimpulkan bahwa infusa daun kayu putih (Melaleuca trichostachya Lindl.) memiliki efek analgesik pada mencit jantan (Mus musculus L.). 


\section{DAFTAR PUSTAKA}

Anonim. 1995, Farmakope Indonesia, Edisi IV, Departemen Kesehatan Republik Indonesia, Jakarta.

Atikaningrum, D. J. 2011, Perbadingan Efektifitas Analgesik Ekstrak Daun Sirih Merah (Piper crocatum) Dengan Aspirin Dosis Terapi Pada Mencit, Fakultas Kedokteran, Universitas Sebelas Maret, Surakarta.

Lutony, T.L. \& Rahmayati, Y. (1994). Produksi Dan Perdagangan Minyak Atsiri. Jakarta: Penerbit Penebar Swadaya.

Pandey, P. V., Bodhi, W., Yudistira, A. 2013, Uji Efek Analgetik Ekstrak Rumput Teki (Cyperus rotundus L.) Pada Tikus Putih Jantan Galur Wistar (Rattus novergicus), Pharmacon Jurnal Ilmiah Farmasi-Unsrat, Volume 2, No. 2.

Puspitasari, H., Listyawati, S., Widyani, T., 2003, Aktivitas Analgetik Ekstrak Umbi Teki (Cyperus rotundus L.) pada Mencit Putih (Mus musculus L.) Jantan, Biofarmasi 1 (2): 50-57.
Seran, Y. N. 2015, Pengaruh Lama Praperlakuan Infusa Kelopak Bunga Rosela (Hibiscus sabdariffa L.) Dosis 1,25 g/kg BB Sebagai Analgetika Pada Mencit Betina Galur Swiss, Fakultas Farmasi, Universitas Sanata Dharma, Yogyakarta.

Sardjono, H., Santoso. O., \& Dewoto, H.R. 1995, Farmakologi dan Terapi, Edisi 4, Gaya Baru, Jakarta.

Syamsudin dan Darmono. 2011, Farmakologi Eksperimental, Universitas Indonesia, Jakarta.

Saifudin A, Rahayu V, dan Teruna HY. 2011, Standardisasi Bahan Obat Alam, Yogyakarta: Graha Media.

Tuhu, P. F. S., Purwantiningsih, Wahyuni, A. S. 2007, Efek Analgetika Ekstrak Etanol Daun Kayu Putih (Melaleuca leucadendron L.) Pada Mencit Jantan. Jurnal Pharmacon, Volume 8, No. 2, 4043.

Tjay, T.H dan Kirana, R. 2007, Obat-Obat Penting Khasiat, Penggunaan dan Efek- Efek Sampingnya, Edisi Keenam, PT. Elex Media Komputindo, Jakarta. 